\title{
Formation and Structuring of Cooperating Structures in Agrarian Production of Modern Russian Economy
}

Kuznetsova E.B.

Kazan Federal University, Institute of Management, Economics and Finance, Kazan, 420008, Russia

\section{Pratchenko O.V.}

Kazan Federal University, Institute of Language, 420008, Kazan, Russia

Email: elvira.kuz.70@mail.ru

\section{Doi:10.5901/mjss.2015.v6n3p751}

\section{Abstract}

The article reveals that the cooperation of labor in the agricultural sector in modern conditions is connected with the specialization of production on the scale of an individual closed household (LPH, KFH, sole proprietorship) and - in terms of the level of socialization of production - acts as a simple form of cooperation, and it is realized in the form of large forms of economic management on the basis of association of part of material-financial and human resources of various agricultural forms of economic management that is reflected in the complex form of agricultural cooperative business.

Keywords: cooperative business, agro-industrial complex, cooperative enterprise, personal subsidiary plot, peasant (farm) household.

\section{Introduction}

Development of agro-industrial complex (APC) of the country is achieved mainly by scientific software that meets modern requirements of production on the innovational basis of in all sectors of the agrarian economy. An innovative approach to the development of agricultural production contributes to the further rise of agricultural economy, to the increase of the efficiency improvement of agricultural production and to the solving of problems of food security of the country. All this requires the economic science to develop and introduce progressive forms of economic management on the basis of new theoretical and practical knowledge with the account of modernization of all branches of agriculture. Studies indicate that production in cooperative production is directly connected with resources of enterprise where - in most cases -their owners work. This factor simplifies the formation of the mechanism of combining the interests of agricultural enterprises and households of population, the associations of their goals in the sphere of production, processing and sales.

In the future, the process of cooperation will wider extend to all the activities of personal subsidiary plots (PSP), peasant (farm) household (PFH) and other forms of economic management. This is due to the fact that the growth of merchantability and production size in individual households will have certain limits - on the one hand, by domestic consumption of owners of individual farms, on the other hand - by the level of economic efficiency of these economic entities. Weak material-technical base and inefficient resource availability determines their low efficiency.

The world practice shows that in the present conditions only the producers, whose economy is based on advanced and resource-saving technology in combination with organizational-economic measures and efficient logistical-resource base, can reach high production efficiency. Analysis of the current state of the agricultural sector of the Russian economy shows that large agricultural enterprises, as well as cooperated agricultural structures have the main influence on the development of its indicators.

Certain aspects of the theory and practice of development of cooperation in the agricultural sector of the economy are studied in the works of R.Owen, S.Fourier, H. Schulze-Delitzsch, F.W. Raiffeisen, F. Lassalle, N.G. Chernyshevsky, M.I. Tugan-Baranovsky, S.L. Maslov, A.V. Chayanov and others [4, 5, 6, 8, 9, 10, 11, 12, 13].

The lack of domestic theoretical research studies in the field of cooperation, especially in modern agrarian sphere, led to the situation that nowadays the ideas of cooperation take a distorted form, and various organizational-economic forms that develop by other laws, without taking into account the specificity of agricultural production, are referred to cooperation. 


\section{Methodology}

As a result of introduction of the innovation strategy the agricultural production can be transformed into different production structures. On the one hand, enterprises with a closed cycle of diversified production - from the start of production to the finished product - appear. On the other hand - cooperative structures where innovations have positive influence on work of employees, transforming it into intellectual - appear. And the labor costs for 1 hundredweight of production tend to decrease. Work in cooperative structures is similar to engineering work, constantly enriched by continuous growth of productivity and efficiency of labor and production.

With the growth of the productive forces of agrarian sphere the agricultural production significantly increases, but the technological disconnection of production and consumption restricts further growth of agricultural production and, in turn, it is the cause of losses at the junction of production and consumption. This complicates the implementation of the Food Security Doctrine. Consequently, in modern conditions the questions of cooperation of labor and production are very relevant, as far as agricultural production gets the final form in the processing industry. Thus, the necessity of cooperative relations is an objective law at the modern stage of development of agricultural production. Co-operation allows to eliminate the discrepancy between production time and working period, between production and consumption, etc. Agricultural production is perishable and low-transportable. Therefore, the final result will be as more effective, as there will be less time and spatial gap between production and consumption. Consequently, the production of food and consumer goods is beyond the frames of closed farming households. Close co-operation of all forms of agricultural production leads to the formation and development of inter-farming cooperation and agro-industrial integration - the highest forms of organization and management of production in the agricultural sector on the innovational basis. Thereby the increasing of agricultural production and its timely delivery to the consumer is provided, and the problem of food provision of the population of the country and industry and the problem of provision of industry by agricultural raw materials - is solved [3].

\section{Results}

The laws of the market economy do not deny - but suggest the most complete account of the specific nature and peculiarities of regional economic space. For many years the presence of significant and reasonable differences between regions finds its concentrated reflection in levels and trends of development of agricultural production.

The period of formation of new agricultural units in the Chuvash Republic, as well as in other regions, has similarities with the economic structure of the peasants of Russia and its characteristic features. These features depend on the regional economic structure, territorial organization of production, innovative transformations taking place on the level of the country and the region, as well as on the natural-climatic conditions in the country and in the regions.

The dynamics of agricultural production in the Russian Federation from 2010 to 2013 is presented on Table 1.

Table 1. Agricultural products and production indices in comparable prices [14]

\begin{tabular}{|c|c|c|c|c|c|c|c|c|}
\hline & \multicolumn{4}{|c|}{ Agricultural production, bln.rubles } & \multicolumn{4}{|c|}{ To the previous year, $\%$} \\
\hline & 2010 & 2011 & 2012 & 2013 & 2010 & 2011 & 2012 & 2013 \\
\hline \multicolumn{9}{|c|}{ Households of all categories } \\
\hline Production, total & 1938,6 & 2461,4 & 2515,9 & 2444,8 & 103,3 & 110,8 & 101,4 & 88,1 \\
\hline including: plant cultivation & 1002,4 & 1306,4 & 1238,9 & 1053,1 & 102,3 & 118,0 & 98,6 & 74,6 \\
\hline Cattle breeding & 929,2 & 1155,0 & 1277,0 & 1391,7 & 104,3 & 103,0 & 104,6 & 102,6 \\
\hline \multicolumn{9}{|c|}{ Agricultural organizations } \\
\hline Agricultural production & 918,5 & 1183,7 & 1141,5 & 1074,8 & 104,9 & 116,2 & 100,8 & 88,5 \\
\hline including: plant cultivation & 490,4 & 637,6 & 542,8 & 402,3 & 103,9 & 124,9 & 93,8 & 70,6 \\
\hline Cattle breeding & 428,1 & 546,1 & 598,7 & 672,5 & 105,9 & 106,1 & 109,2 & 104,8 \\
\hline \multicolumn{9}{|c|}{ Personal subsidiary plots of population } \\
\hline Agricultural production & 856,6 & 1068,5 & 1184,7 & 1204,3 & 101,6 & 102,1 & 102,9 & 88,6 \\
\hline including: plant cultivation & 388,5 & 501,5 & 552,9 & 537,7 & 100,6 & 104,6 & 105,8 & 80,2 \\
\hline Cattle breeding & 468,1 & 567,0 & 631,8 & 666,6 & 102,4 & 99,9 & 100,4 & 95,9 \\
\hline \multicolumn{9}{|c|}{ Peasant (farm) households } \\
\hline Agricultural production & 156,5 & 209,2 & 189,7 & 165,7 & 105,2 & 127,8 & 97,0 & 82,5 \\
\hline including: plant cultivation & 123.5 & 167,3 & 143,2 & 113,1 & 102.7 & 133,3 & 95,1 & 75,6 \\
\hline Cattle breeding & 33,0 & 41,9 & 46,5 & 52,6 & 113,3 & 107,2 & 104,2 & 103,7 \\
\hline
\end{tabular}


Because of unfavorable weather conditions the decrease of production of plant cultivation was in the last three years: if in 2008 its share in total production output was 53,1\%, in 2010 it was only $43,1 \%$, respectively, the share of products of cattle breeding increased. The largest decrease of share of crop production was in agricultural organizations was from $53,9 \%$ in 2008 to $37,4 \%$ in 2010. During this period in peasant (farm) households the share reduced from $79,9 \%$ to $68,3 \%$, in personal subsidiary plots of population - from $46,9 \%$ to $44,6 \%$. As a result, the share of agricultural enterprises in the total volume of crop production decreased from $48,1 \%$ in 2008 to $43,9 \%$ in 2010 , of peasant (farm) households from 8,5 to $6,8 \%$. The share of production of personal subsidiary plots of population increased from $43,4 \%$ to $49,3 \%$ [14] (Table 2).

Table 2. Indices of agricultural production in federal districts of the Russian Federation in 2013, \% to 2002

\begin{tabular}{|c|c|c|c|}
\hline \multirow{2}{*}{} & \multicolumn{3}{|c|}{ Production } \\
\cline { 2 - 4 } & Total & Plant cultivation & Cattle breeding \\
\hline Russian federation & 88,1 & 74,6 & 102,6 \\
\hline Central Federal District & 84,8 & 65,7 & 104,4 \\
\hline Northwestern FD & 102,0 & 97,6 & 104,7 \\
\hline Southern FD & 99,6 & 98,1 & 101,8 \\
\hline North Caucasian FD & 103,8 & 104,0 & 103,6 \\
\hline Volga FD & 75,1 & 47,5 & 98,1 \\
\hline Urals FD & 89,6 & 74,9 & 101,9 \\
\hline Siberian FD & 94,8 & 87,8 & 101,2 \\
\hline Far Eastern FD & 101,5 & 101,3 & 101,7 \\
\hline
\end{tabular}

Organizational structure of management within the frames of cooperative production can be represented in the following way (Fig. 1).

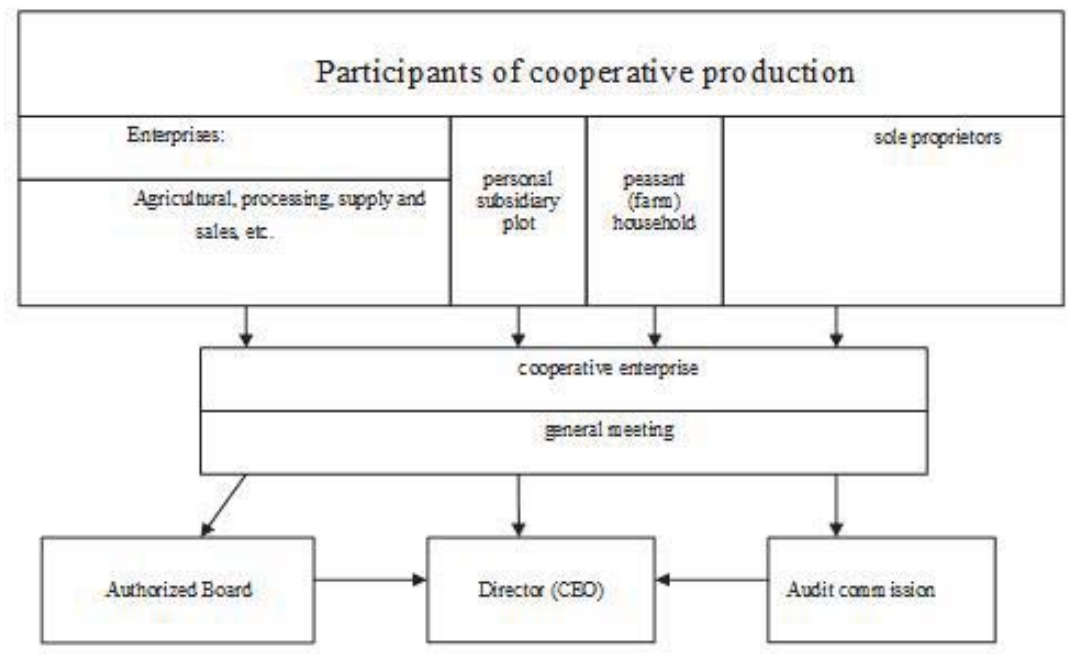

Fig. 1. Proposed management structure in co-operative enterprise

Presence of an enterprise-integrator with qualified specialists and workers as a part of the cooperative enterprise is important condition for its successful operation.

In the 1990 s of the $20^{\text {th }}$ century the scope of the process of cooperation in Russia was changed by its rollback. In agriculture the real cooperatives started to take less space. Cooperation mainly transformed into trade. Premises of the former state stores, canteens, etc. were given for it. Cooperation as a form of rational economic management and the subject of ownership relations stopped to be mentioned in official documents and in the media. Such quick change in the development of cooperation - from takeoff to decay - was the result of absence of state policy in the sphere of agroindustrial complex. Because of this the contradictions between cooperatives that arose in the trade, and population appeared: high prices for products of cooperatives, absence of government regulation, etc. 
Thus, the revival of cooperation as a special socio-economic form in agricultural production would bring stability in the society and would significantly expand the frames in provision of food security of the country. Formation of real cooperative structure is aimed at improving the market situation by increasing the output of production of goods and services, at decrease of rural unemployment and decrease of social tension in rural areas and increase of the standard of living of rural population.

Sustainability of development of cooperative structures can be determined by the dynamics of the output of production per one employee by the following formula:

$\ni_{p}=\left(\left(\mathrm{B}_{q} / \mathrm{u}_{i+n} / \mathrm{H}_{\mathrm{i}+n}\right) /\left(\mathrm{B}_{q / u_{i}} / \mathrm{H}_{\mathrm{i}}\right)\right) \times 100$,

$\ni_{p}-$ output of production produced by cooperative structures per one employee;

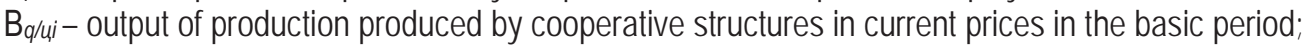

$n$ - period of functioning (from 1 to 5 years);

$\mathrm{B}_{q / \mathrm{u} i+n}$ - output of production produced by cooperative structures in current prices in the i-period;

$\mathrm{H}_{i}$ - number of permanent employees in cooperative structures in basic period;

$\mathrm{H}_{i+n}$ - number of permanent employees in cooperative structure in i-period;

\section{Statements}

The following principles are the main principles of sustainable growth of the process of co-operation in modern agrarian production:

- openness: for formation of this mechanism it is necessary to use the methods of the interactive approach. Expected results and problems of co-operative structures should be covered in the local media, discussed in working groups, etc. All available resource materials and sociological studies should be used for comparative analysis;

- completeness: all variants of possible types of cooperative activities by which it is possible to pursue the interests of business entities and thereby to increase their income, are considered. At the same time, such activities should be fully grounded from the legal, economic and social points of view;

- voluntariness: participation of business entities (personal subsidiary plots (PSP), peasant (farm) household (PFH), KFH, sole proprietors, etc.) in co-operative production should come from participants themselves in accordance with their needs and interests, i.e., of the features of economic and social behavior of different categories of business entities.

- emphasis on local resources: achievement of goals is achieved by mobilizing the local material and technical, financial and human resources of participants of cooperative structures. However, this does not exclude the use of external sources of resource support - bank loans.

- state support: participants of cooperative production should feel state support in marketing and supply, as well as in the processing of agricultural products. This is due to the fact that agricultural products are perishable. Therefore, it is necessary to implement it very quickly or to arrange the processing with the account of interests of population and the state $[1,2]$.

Practice shows that large agricultural units that have advantages over small producers, are the basis for the formation and development of cooperative structures. These advantages are the possibility to use a high-performance machinery and equipment, advanced technologies, as well as financial and human resources.

In general, agricultural co-operation is determined by difficult economic and social situation in the countryside, where economic entities (PSP, PFH, sole proprietors, etc.) are not able to maintain production or to perform services on their own. In this case, the cooperative structures are a kind of way of protection and pursue of economic and social interests of rural population through self-organization, that is, by an informal association of their own funds, which largely contributes to the solution of problems to ensure the food supply security of the country.

\section{Reeferences}

Bagautdinova N.G., Murtazina G.R., Fazlieva E.P., Naida A.M. Improvement of the regional management system using the labor potential index // World Applied Sciences Journal, 27(1), 2013, 107-111.

Bagautdinova N.G., Panasyuk M.V., Gafurov I.R. Wavelet analysis of the territorial socio-economic system dynamics // World Applied Sciences Journal, 27(13), 2013, 62-66.

Batle L. Las woperativas agrarias // Cultivador mod. 1990. Vod. 843.p.62 -65.

Cooperative Feed and Animal Health Operations. USDA. ACS CIR 1. Sec. 21. Washington. D.C. 1991. 37 p. 
Dairy Farmers Participation in Cooperatives. USDA. ACS. CIR 34. Washington. D.C. 1990. 14 p.

Economic Indicators of the Farm Sector. National Financial Summary. 1989. USDA. ERS ECIEC 9-2. Washington. D.C. 1991. P. 37, 45, 82.

Family farming in Finnisch agriculture // family Farming Possibilities. №61. 1990.p. 7-16.

Farmer Cooperative Theory: Recent Developments. USDA. ACS. RR 84. Washington. D.C. 1989. 30 p.

How do you acquaint employees with basics of their cooperative company? // Farmer Cooperatives. June 1990. Vol. 57. № 3. P. 7.

Organizations Serving Cooperatives. USDA. ACS. CIR 1. Sec. 5. Washington. D.C. 1989. 38 p.

Panasyuk, M.V., Bagautdinova, N.G., Safiullin, L.N., Novenkova, A.Z. Territorial approach to solving the region strategic management problems // World Applied Sciences Journal, 27(13), 2013, 149-153.

Tschajanoff A. Die Lehre von der bauerlichen Wirtschaf. Berlin, 1923.

Yoshio I. N. G. Chemyshevsky: Pioneer of the Russian Cooperative Movement // Imperial power and development: papers on prerevolutionary russian histori. Selected Papers of the Third World Congress for Soviet and Fast European Studies. Washington, 1988. P. 134-151. http://www.km.ru/referats/334521-stanovlenie-teorii-kooperativnogo-sotsializma-v-ssha-zapadnoi-evrope-irossii-xix-nachalo-xx- Cooperative Organization and Structure. USDA. ACS. CIR 1. Sec. 6. Washington. D.C. 1990. 55 p.

Bagautdinova, N.G., Eshugova, S.K., Saipullaev, U., Karasik, E.A. Methods of technology commercialization in projects of the agrofood system (AFS) development // World Applied Sciences Journal, 27(13), 2013, 48-52.

Kirshin I.A., Datsyk A.A., Titov A.V. Forecasting the Dynamics of an Innovative Cycle. - World Applied Sciences Journal (Economics, Management and Finance). - 2013. - №27. - P. 197 - 201.

Glebova I.S., Sadyrtdinov R. and Rodnyansky D. Impact Analysis of Investment Attractiveness of the Republic of Tatarstan on Fixed Investments of its Leading Companies // World Applied Sciences Journal 26 (7): 911-916, 2013.

Glebova I.S., Khabibrakhmanova R. and Yasnitskaya Y. The Analysis of the Impact of the Investment Attractiveness Factors of the Region on the Fixed Capital Investments in the Economy of the Republic of Tatarstan II Middle-East Journal of Scientific Research 17 (10): 1498-1502, 2013. 